American Journal of Applied Sciences 9 (6): 902-905, 2012

ISSN 1546-9239

(C) 2012 Science Publications

\title{
Ordaining for Learning Culture: Educational Conservation and Development of Buddhist Monk Universities for Isan People with Limited Opportunity
}

\author{
Sanit Sumhiram, Songkoon Chantachon and Kosit Paengsoi \\ Faculty of Cultural Science, Mahasarakham University, Maha Sarakham, Thailand
}

\begin{abstract}
Problem statement: Buddhist monk universities in Isan (northeast Thailand) have problems of lacking Buddhist monk students. The number of people ordained for learning decreases because Isan people do not like ordaining for learning. In order to adjust the condition of problem to catch up with current conditions, this research study was conducted. The purpose of this research was to examine the background, current conditions, problems and process of conserving and developing ordaining for learning at Buddist monk universities for people with limited opportunity in Isan. Approach: The research area covered Khon Kaen, Nakhon Ratchasima and Roi Et provinces. Each of these provinces had campuses of the 2 Buddhist monk universities located in the same province. These universities had continuously been proving education at the undergraduate and graduate studies level up to present. The research procedure used the qualitative research methodology. Data were collected from documents, related literature and field studies using survey, observation, interviews and focus group discussion from a group of totally 208 informants. The findings were presented by means of a descriptive analysis. Results: There were 2 universities: (1) Mahachulalongkornrajavidyalaya University provided education at 3 locations: Khon Kaen Campus, first offered in 1986; Nakhon Ratchasima Campus, first established in 1987 and Roi Et Classroom, first established in 1999 according to the project for classroom extension by Khon Kaen Campus. (2) Mahamakut Buddhist University provided education at 3 locations: Isan Campus, located in Khon Kaen province, first established in 1990; Roi Et Campus, first established in 1994 and Koraj Education Center, located in Nakhon Ratchasima province, first established in 2006. For current conditions and problems of ordaining for learning at Buddhist monk universities for people with limited opportunity in Isan, Mahachulalongkornrajavidyalaya University at present provides education at certificate, bachelor's degree, master's degree and doctoral degree levels at 3 locations. Khon Kaen Campus offers 15 majors, Nakhon Ratchasima Campus offers 10 majors and Roi Et Classroom offers 7 majors. Mahamakut Buddhist University provides education at certificate, bachelor's degree and master's degree levels at 3 locations. Isan Campus offers 18 majors, Roi Et Campus offers 13 majors and Koraj Education Center offers 15 majors. As for the problem conditions, both of the Buddhist monk universities in Isan were not supported by the government agency as they should be. There were limitations of curricular offering. There were problems of monk's travelling and appropriate behaviors, these could cause people in general to decrease their faith in monks. They did not like ordaining for learning. The process of conservation and development of ordaining for leaning at Buddhist monk universities in Isan could be made by supporting each Buddhist monk university in Isan and enhancing people to be more interested in ordaining for learning to be a choice of education. It would be creation of educational opportunity. Different resources concerning education of people with limited opportunity could be accessed. Conclusion: Buddhist monk universities in Isan provide education at certificate, bachelor's degree, master's degree and doctoral degree levels. It is educational opportunity extension, education for developing monks' education, social development, economic development and dissemination of ordaining for learning culture at Buddhist monk universities in northeast Thailand to be widely known. Buddhist monks and novices can not have to travel to study further outside their domiciles.
\end{abstract}

Key words: Ordaining for learning culture, conservation and development, Buddhist monk universities in northeast Thailand, people with limited education opportunity

Corresponding Author: Sanit Sumhiram, Faculty of Cultural Science, Mahasarakham University, Maha Sarakham, Thailand 902 
Am. J. Applied Sci., 9 (6): 902-905, 2012

\section{INTRODUCTION}

The values in ordaining for learning of most Thai Buddhists has changed. Thai people in Isan decrease less ordaining for learning. Ordaining to become novices and monks is mostly only the practice following the adhered tradition. Their appeared change in education at Buddhist monk universities with their campuses located in Isan in 1992. That was, a large amount ordaining for learning of Isan people decreased. Therefore, there were adjustment of the guideline for operation by offering opportunity for novices and monks to study Buddhist course together with various modern course, causing more people to ordain for learning because they cause receive Dhamma knowledge as well as worldly knowledge. This was the regarded as the important turning point of education through ordaining for learning.

\section{MATERIALS AND METHODS}

The qualitative research methodology was used. Data were collected from documents, related literature and field studies. The research was conducted using a basic survey form, a non-structured interview form and focus group discussion with a group of totally 208 informants. They included: (1) A group of 16 key informants consisting of vice-presidents of Buddhist monk universities in Isan, (2) a group of 72 casuals informants consisting of Buddhist monk faculties, layman faculties and community leaders; (3) and 120 general informants consisting of monk students and people in general. The collected data were checked for correctness and completeness using the methodological triangulation technique. The research findings were checked by experts in Buddhism and subsequently presented by means of a descriptive analysis.

\section{RESULTS}

The background of ordaining for learning at Buddhist monk universities in Isan: Ordaining to become monk hood to study at the higher education level in Isan has background according to the developments of the two Buddhist monk universities in Isan as follow: (1) Mahachulalongkornrajavidyalaya University has provided education at 3 locations in Isan. They are Khon Kaen Campus established in 1985 to be a place for ordaining for learning at the higher education level in Isan. Formerly it was located at Wat [temple] Dhat, first offered in 1986. It was the Faculty of Buddhism, Bachelor of Arts Program in Buddhism with 21 monk students. Later, a large number of Buddhist monk and novices in local area and from neighboring country were interested in studying. There were adequate school buildings for education provision so in 2007 the university was move to be on Khon Kaen-Nam Pong Road, Tambon Kok Si, Muang Khon Kaen District, Khon Kaen province by providing education and discriminating Buddhism in Isan and Indochinese region. Nakhon Ratchasima Campus was located on Chat Pattana Road, Muang Nakhon Ratchasima District, Nakhon Ratchasima Province. The development was from Nakhon Ratchasima Buddhist Monk College, established in 1986. Later in 1987, it was upgraded to be Mahachulalongkornrajavidyalaya University Nakhon Ratchasima Campus. It offered bachelor's degree in The Faculty of Buddhist in 1987, Faculty of Humanities in 1990, Faculty of Education in 1991 and Faculty of Social Sciences in 1993; at certificate level in 2 majors. It offered master's degree in 2006, Roi Et Classroom, located at Wat Sra Thong, Hai Sok Road, Muang Roi Et District, Roi Et province, established in 1999 according to the classroom extension project by Mahachulalongkornrajavidyalaya University Khon Kaen Campus and education was first provided in the same year in Faculty of Buddhist, Bachelor of Arts Program in Buddhism with 49 monk students. Education was provided and extended to other major and later at master's degree (2) Mahamakut Buddhist University provided education in Isan in 3 locations: Isan Campus, located in Khon Kaen province, established in 1990 as the first campus in Isan, formerly it was located at Wat Sri Chan, Muang Khon Kaen District, Khon Kaen province and later move to located at Ban Non Chai, Rat Kha Nung Road, Muang Khon Kaen District, Khon Kaen province in 1999. In the first period it offered bachelor's degree and later extended to master's degree. Roi Et Campus was first established in 1994 formerly the temporary offer it was at Wat Nuea, Muang Roi Et District, Roi Et province, later move to located at Wat Sri Thong Phaiboonvanaram, By Pass Road [ring road], Muang Roi Et District, Roi Et province. During the first period bachelor's degree programs were offered and later offered graduate studies. Koraj Education Center was first established in 2006 at Wat Sut Tha Chin Da, Muang Nakhon Ratchasima District, Nakhon Ratchasima province, In first period there were 2 faculties: Faculty of Religion and Philosophy and Faculty of Social Science. Later 2 faculties were offered and it extended to graduate studies in Master of Arts Program in Buddhist Study in 2008.

Current conditions and problems of ordaining for learning at Buddist monk universities for people with limited opportunity in Isan: The current condition of ordaining for learning at Buddist monk universities for people with limited opportunity in Isan are as follow: (1) Mahachulalongkornrajavidyalaya 
University, Khon Kaen Campus offers Faculty of Buddhism, Faculty of Education, Faculty of Social Science and Faculty of Humanities. It provides at certificate level in 3 majors, bachelor's degree 10 majors, master's degree 1 major Master of Arts Program in Buddhist Studies and doctoral degree 1 major Doctor of Philosophy Program in Buddhist Study for education in provision in Buddhist major for integration into various modern sciences. Nakhon Ratchasima Campus offers Faculty of Buddhism, Faculty of Humanities, Faculty of Education and Faculty of Social Science. It provides at certificate level in 2 majors, bachelor's degree 7 majors and master's degree 1 major Master of Arts Program in Buddhist Studies, Roi Et Classroom offers Faculty of Buddhism and Faculty of Social Science. It provides education at the bachelor's degree in 6 majors, master's degree 1 major Master of Arts Program in Buddhist Studies. (2) Mahamakut Buddhist University provides education at certificate, bachelor's degree and master's degree levels at 3 locations. Isan Campus offers Faculty of Religion and Philosophy, Faculty of Education, Faculty of Social Science, Faculty of Humanities and Graduate School. It offers bachelor's degree 14 majors, master's degree 4 major Master of Arts Program in Buddhist Studies, Program in Buddhism and Philosophy, Program in Politics and Government, Program in Education Management. Roi Et Campus offers Faculty of Religion and Philosophy, Faculty of Education, Faculty of Social Science and Graduate School. It offers bachelor's degree in 8 majors, graduated certificate [post bachelor degree level] 2 majors, master's degree 3 major Master of Arts Program in Buddhism and Philosophy, Program in Politics and Government and Program in Education Management. Koraj Education Center offers Faculty of Religion and Philosophy, Faculty of Education, Faculty of Social Science and Faculty of Humanities. It offers bachelor's degree in 14 majors and master's degree 1 major Master of Arts Program in Buddhist Studies (Hamrah, 2012). The problem condition of ordaining for learning at Buddist monk universities for people with limited opportunity in Isan are as follow: All of the 2 Buddhist monk universities located in the 6 locations as mentioned have not received supports from government agency as they should. They have limitation of offering program. Also, the program [curricular] do not meet the needs of monk students. Travelling who study at each campus is not convenient. Presentations of the information about inappropriate behaviors of some monks and novices make people decrease their faith. These things cause people at present not like to ordaining for learning (Richter and Schumacher, 2011).
The process of conservation and development of ordaining for learning at Buddist monk universities for people with limited opportunity in Isan: The result reviewed that in order to generate conservation and development education for people with limited educational opportunity. The government should support these Buddhist monk universities in each location in Isan in every aspect. Each university should offer program or major with meet the needs Buddhist monks and novices also these should be adequate dormitories and transportation. In addition, positive news about Buddhist monks and novices who do good deed and practices on different media to be good example of ordaining for learning. People in general should be promoted to be interested in ordaining for learning different principle of Dhamma. If Buddhist monks and novices can train themselves to endure hardship they will be able to ordaining for learning until they complete education from the Buddhist monk universities.

\section{DISCUSSION}

From surveying the problem and obstacles at Buddhist monk universities in Bangkok, problem can be summarized in this order: Lack of instructors, monk students and hardly alert in studying, lack interest in learning and welfare and are bored of the program. The universities lack regular budgets for operation and education provision. They lack school buildings and residents for monk students, lack instructional material and lack coordination between government official with monk student universities. Study time is limited. Monk students are a long way from their universities. Also, people do not cooperate in sending their children to ordain in learning (Karchner-Ober and Dippel, 2011). Buddhist monk universities in Isan are extension from Buddhist monk universities in Bangkok. Difference divisions are divided according to center universities. Each part section has a Buddhist monk as a director. So management is not independent. The directors must wait for order from the central. The number of personal at each university is limited, causing operation not to be fluent material and supply are inadequate with word load. Allotted supporting budgets are very limited when compared with other government universities (Kaeolan et al., 2011). It is difficult in Isan to be academic excellent. The number of instructors in each major is limited and their qualification are not in required majors. The instructors lack specific experiences, being obstacles to learning and instruction. The Buddhist monk students who are ordain for learning have different background of knowledge and maturity and 
lack enthusiasm about learning (Chantarasombat, 2011). The program still lack diversity and were appropriate for serving society. The result of the research reviewed that the Buddhist monk universities progressed in term of space and buildings. The program were improved to meet Buddhist monk students. However, government supports were not adequate. Moreover, travelling to study at each campus was not convenient (Nguanthaisong et al., 2011).

\section{CONCLUSION}

This study ordaining for learning culture: educational conservation and development of Buddhist monk universities for people with limited opportunity in Isan aimed to examine the background, current conditions, problem and the process of conserving and development of education provision at Buddist monk universities for people with limited opportunity in Isan in 3 provinces: Khon Kaen, Nakhon Ratchasima and Roi Et which ordaining for learning at Buddhist monk universities in Isan as of conservation traditional ordaining for learning and development of varions modern subjects technique to suit Buddhist monks and novices in Isan at present. In addition, Buddhist monk universities still offen master's degree program and Ph.D. programs opportunity as educational extension. It was a study of education development for Buddhist monks, social development, economic development and disimination of ordaining for learning of Buddhist monk universities in northeast Thailand to be wellknown. Buddhist monks and novices in Isan will not have to travel to study in Bangkok the capital of Thailand or to study abroad.

\section{ACKNOWLEDGEMENT}

My sincere thanks go to The Commission on Higher Education for providing a scholarship according to The Strategic Scholarships Fellowships Frontier Research Networks in 2008. The researchers express their sincere appreciation and thanks for all of those who supported in one way or another.

\section{REFERENCES}

Chantarasombat, C., 2011. Developing a community enterprise eonsultant network for isan. J. Soc. Sci., 7: 611-618. DOI: 10.3844/jssp.2011.611.618

Hamrah, S.Z., 2012. Role of virtual education in higher education from the view of existence philosophy. J. Soc. Sci., $\quad$ 8: 207-215. DOI: $10.3844 /$ jssp.2012.207.215

Kaeolan, P.K.W.P., B. Yodmalee and S. Phothisane, 2011. Buddhist monk preachers: A study of preaching arts for increasing faith in Buddhism of Isan people. J. Soc. Sci., 7: 271-273. DOI: 10.3844 /jssp.2011.271.273

Karchner-Ober, R. and U. Dippel, 2011. Sustainability Education-A Challenge for South-East Asia and Europe. J. Soc. Sci., 7: 90-99. DOI: 10.3844/jssp.2011.90.99

Nguanthaisong, P., S. Phothisane and S. Laoakka, 2011. Development of cultural management and inheritance by community participation. J. Soc. Sci., 7: 161-167. DOI: 10.3844/jssp.2011.161.167

Richter, T. and K.P. Schumacher, 2011. Who really cares about higher education for sustainable development? J. Soc. Sci., 7: 24-32. DOI: $10.3844 /$ jssp.2011.24.32 